\title{
Evaluation of the efficacy and safety of transplantation of adipose-derived stem cells in the treatment of refractory fistulizing Crohn's disease
}

\author{
Avaliação da eficácia e segurança do transplante de células-tronco mesenquimais autólogas \\ derivadas do tecido adiposo \\ Evaluación de la eficacia y seguridad del trasplante de células madre mesenquimales autólogas \\ derivadas del tejido adiposo en el tratamiento de la enfermedad de Crohn fistulizante refractaria
}

Received: 01/02/2022 | Reviewed: 01/07/2022 | Accept: 01/14/2022 | Published: 01/15/2022

\author{
Luana Bernardi \\ ORCID: https://orcid.org/0000-0002-8650-3105 \\ Universidade Federal de Mato Grosso do Sul, Brasil \\ E-mail: bernardi1284@gmail.com \\ Laynna de Carvalho Schweich-Adami \\ ORCID: https://orcid.org/0000-0002-9838-7340 \\ Universidade Federal de Mato Grosso do Sul, Brasil \\ E-mail: laynnaschweich@gmail.com \\ Carlos Henrique Marques dos Santos \\ ORCID: https://orcid.org/0000-0001-5226-0355 \\ Universidade Federal de Mato Grosso do Sul, Brasil \\ E-mail: chenriquems@yahoo.com.br \\ Thiago Franchi Nunes \\ ORCID: https://orcid.org/0000-0003-0006-3725 \\ Universidade Federal de Mato Grosso do Sul, Brasil \\ E-mail: thiagofranchinunes@gmail.com \\ Rodrigo Juliano Oliveira \\ ORCID: https://orcid.org/0000-0003-3514-3346 \\ Universidade Federal de Mato Grosso do Sul, Brasil \\ Universidade Estadual de Londrina, Brasil \\ E-mail: rodrigo.oliveira@ufms.br \\ Andreia Conceição Milan Brochado Antoniolli da Silva \\ ORCID: https://orcid.org/0000-0002-2525-7019 \\ Universidade Federal de Mato Grosso do Sul, Brasil \\ E-mail: andreia@corporesanosaude.com.br
}

\begin{abstract}
Aim: The treatment of perianal fistulas in Crohn's disease (CD) is a challenge. Adipose-derived stem cells (ADSCs) are an option for treating fistulas, but their behavior at the injection site still needs to be further investigated. The efficacy and safety of autologous transplantation of ADSCs of patients with refractory perianal fistulizing CD was evaluated. Method: A total of 6 patients (18-48 years) were recruited. The intervention was three applications of autologous ADSCs (total of $3 \times 10^{7}$ cells). The evaluations happened in the 12th and 24th week after the first application, been considered primary and secondary efficacy outcomes, safety outcomes, anthropometric and food quality assessments. Results: Three patients completed the study and been treated 8 fistulas with ADSCs, none application-related effect was observed. The healing closure of the external part occurred in four fistulas, with local reepithelialization, and also two closed completely in the 12th week. The Van Assche index indicates improvement in only one of the patients. On the other hand, the Clinical Perianal Disease Activity Index and the quality of life assessment indicated progress for the three patients until the end of the study. By the CD Simple Endoscopic Score, two patients had the disease endoscopically inactive at the end of follow-up. Most of the anthropometric measurements were adequate and the foods that had low consumption throughout the study, in conformity for the three evaluated, were those belonging to the group of beans. Conclusion: It is concluded that autologous ADSCs have clinical potential to safely treat refractory perianal fistulizing CD.
\end{abstract}

Keywords: Cell Therapy; Adipose Tissue Derived Mesenchymal Stem Cell; Crohn's Disease.

\section{Resumo}

Objetivo: O tratamento das fístulas perianais na doença de Crohn (DC) é um desafio. As células-tronco derivadas do tecido adiposo (CTMDA) são uma opção para o tratamento de fístulas, mas seu comportamento no local da injeção ainda precisa ser investigado. A eficácia e segurança do transplante autólogo de CTMDA de pacientes com DC 
fistulizante perianal refratária foram avaliadas. Método: Um total de 6 pacientes (18-48 anos) foram recrutados. A intervenção consistiu em três aplicações de CTMDA autólogas (total de $3 \times 10^{7}$ células). As avaliações ocorreram na $12^{\mathrm{a}}$ e $24^{\text {a }}$ semanas após a primeira aplicação, sendo considerados desfechos primários e secundários de eficácia, desfechos de segurança, avaliações antropométricas e de qualidade alimentar. Resultados: Três pacientes completaram o estudo e foram tratadas 8 fístulas com CTMDA, nenhum efeito relacionado à aplicação foi observado. $\mathrm{O}$ fechamento cicatricial da parte externa ocorreu em quatro fístulas, com reepitelização local, e também duas fecharam completamente na $12^{\mathrm{a}}$ semana. O índice de Van Assche indicou melhora em apenas um dos pacientes. Por outro lado, o Índice Clínico de Atividade da Doença Perianal e a avaliação da qualidade de vida indicaram evolução para os três pacientes até o final do estudo. Pelo CD Simple Endoscopic Score, dois pacientes apresentaram a doença endoscopicamente inativa ao final do seguimento. A maioria das medidas antropométricas foi adequada e os alimentos que tiveram baixo consumo ao longo do estudo, conforme para os três avaliados, eram aqueles pertencentes ao grupo do feijão. Conclusão: Conclui-se que as CTMDA autólogas têm potencial clínico para tratar com segurança a DC fistulizante perianal refratária.

Palavras-chave: Terapia Celular; Célula-Tronco Mesenquimal Derivada de Tecido Adiposo; Doença de Crohn.

\section{Resumen}

Objetivo: El tratamiento de las fístulas perianales en la enfermedad de Crohn (EC) es un desafío. Las células madre derivadas del tejido adiposo (ADDC) son una opción para el tratamiento de las fístulas, pero su comportamiento en el lugar de la inyección aún debe investigarse. Se evaluó la eficacia y seguridad del trasplante autólogo de ADCC de pacientes con EC fistulizante perianal refractaria. Método: Se reclutó un total de 6 pacientes (18-48 años). La intervención consistió en tres aplicaciones de CTMDA autólogo (total de 3x107 células). Las evaluaciones se llevaron a cabo en las semanas 12 y 24 después de la primera aplicación, considerando los resultados de eficacia primarios y secundarios, los resultados de seguridad, las evaluaciones antropométricas y de la calidad de los alimentos. Resultados: Tres pacientes completaron el estudio y 8 fístulas fueron tratadas con CTMDA, no se observó ningún efecto relacionado con la aplicación. El cierre de la cicatriz de la parte externa ocurrió en cuatro fístulas, con reepitelización local, y también en dos que cerraron por completo en la $12^{\mathrm{a}}$ semana. El índice de Van Assche indicó mejoría en solo uno de los pacientes. Por otro lado, el Índice de Actividad Clínica de la Enfermedad Perianal y la evaluación de la calidad de vida indicaron la evolución de los tres pacientes al final del estudio. Utilizando el CD Simple Endoscopic Score, dos pacientes tenían la enfermedad endoscópicamente inactiva al final del seguimiento. La mayoría de las medidas antropométricas resultaron adecuadas y los alimentos que tuvieron bajo consumo a lo largo del estudio, según los tres evaluados, fueron los pertenecientes al grupo del frijol. Conclusión: Se concluye que las ADCRC autólogas tienen potencial clínico para tratar de forma segura la EC fistulizante perianal refractaria.

Palabras clave: Terapia Celular; Célula Madre Mesenquimal Derivada del Tejido Adiposo; Enfermedad de Crohn.

\section{Introduction}

Crohn's disease (CD) is an inflammatory bowel disease (IBD) that is characterized by chronic, transmural and recurrent inflammation of any part of the gastrointestinal tract (Torres et al., 2017), and that results from the interaction between genetic predisposition, environmental factors and uncontrolled immune responses (Zhang et al., 2018). It can lead to symptoms such as abdominal pain, diarrhea with passing blood or mucus, intestinal obstruction (Torres et al., 2017), fatigue, weight loss, fever, anemia and also perianal lesions such as fissures, ulcers, abscesses and fistulas (Ott; Scholmerich et al., 2013). Others may present extra-intestinal systemic manifestations and, together, these factors increase the risk of hospitalization, surgeries and impact on quality of life (Torres et al., 2017). The highest prevalence is in European and North American countries, however, in newly industrialized countries cases have increased ( $\mathrm{Ng}$ et al., 2017). Some studies report that the incidence of CD in Brazil are incresing ( $\mathrm{Ng}$ et al., 2017), from 0.81 (1990) to 1.94 (2016) per 100.000 people a year in almost every region ( $\mathrm{Ng}$ et al., 2018).

Fistulas are manifestations that characterize a penetrating disease (Ott; Scholmerich et al., 2013), those of the most prevalent is perianal type (Eglinton et al., 2012). Its treatment represents a challenge, as there are few pharmacotherapies aimed at this type of manifestation (Gecse et al., 2014). The use of the anti-tumor necrosis factor alpha agent (anti-TNF- $\alpha$ ) infliximab is indicated and also antibiotics and thiopurines (Aguilera-Castro et al., 2017). But even so, the failure and relapse rates of combined medical and surgical treatments are observed in $80 \%$ and $50 \%$ of cases, respectively. In view of this, there is a need for more effective treatments, especially for patients who are refractory to existing therapies (Panes et al., 2018).

Therapy with ADSCs is considered a treatment option for fistulas in patients with CD that do not respond to conventional and/or biological treatments. However, a few informations is known about the behavior of these cells within the 
injection site. But their use in perianal tissue damaged by the disease is justified, mainly, by the immunomodulatory properties, tissue regeneration, wound healing, angiogenesis and by ability to migrate to injury sites on the body (Carvello et al., 2019). Thus, studies have been obtaining promising results in relation to conventional therapies, with little or none side effects (Molendijk et al., 2015; Avivar-Valderas et al., 2019), however there is still no study being developed with patients in Brazil. Thus, the aim of this study was to evaluate the efficacy and safety of autologous transplantation of ADSCs in patients with refractory perianal fistulizing $\mathrm{CD}$.

\section{Methodology}

\section{Casuistry}

A total of 6 patients from the University Hospital Maria Aparecida Pedrossian and the Regional Hospital of Mato Grosso do Sul were recruited and enrolled in the study. The age ranged from 18 to 51 years, 2 of them were female and all of them signed the free and informed consent form before enrollment.

The following inclusion criteria were applied: voluntary patients, of both genders, with a minimum age of 18 years, should had diagnosis of fistulizing CD by biopsy or histological examination, refractory to conventional drug treatment, biological and surgical, and who accepted participate in all stages of the study. Furthermore, immunomodulators and anti-TNF drugs were maintained at stable doses throughout the study.

Exclusion criteria were: patients not refractory to conventional drug and/or surgical treatment; diagnosis of autoimmune disease or inflammatory bowel disease other than $\mathrm{CD}$; infection that required antibiotic treatment; carriers of the Human Immunodeficiency Virus (HIV); with a previous history of treatment for cancer or other malignant disease, as well as other comorbidities, such as heart disease, liver disease, active infectious diseases, toxic megacolon and those with the presence of active tuberculosis confirmed by chest X-ray; who presented physical conditions that excluded the possibility of undergoing liposuction; pregnant and breastfeeding women.

\section{Study protocol}

The study was made in accordance with the principles of the Declaration of Helsinki, and the protocol was approved by the National Research Ethics Committee (CONEP) (nº 3.690.658).

This work was designed as an analytical, experimental and longitudinal trial (Almeida Filho \& Rouquayrol, 2011) to assess the efficacy and safety of ADSCs in the treatment of refractory perianal fistulizing CD. Patients were allocated to the intervention group and received the following treatment: 3 ADSCs infusions, each 2 weeks apart from week 0, and the patient assessment times were: (i) at the three times of infusion, (ii) within 8 weeks prior to week 0 (period T0 or pre-intervention), (iii) within 12 weeks after week 0 (period T1 or post-intervention) and (iv) within 24 weeks after week 0 (T2 or follow-up period) (Figure 1). 
Figure 1 - Study protocol overview.

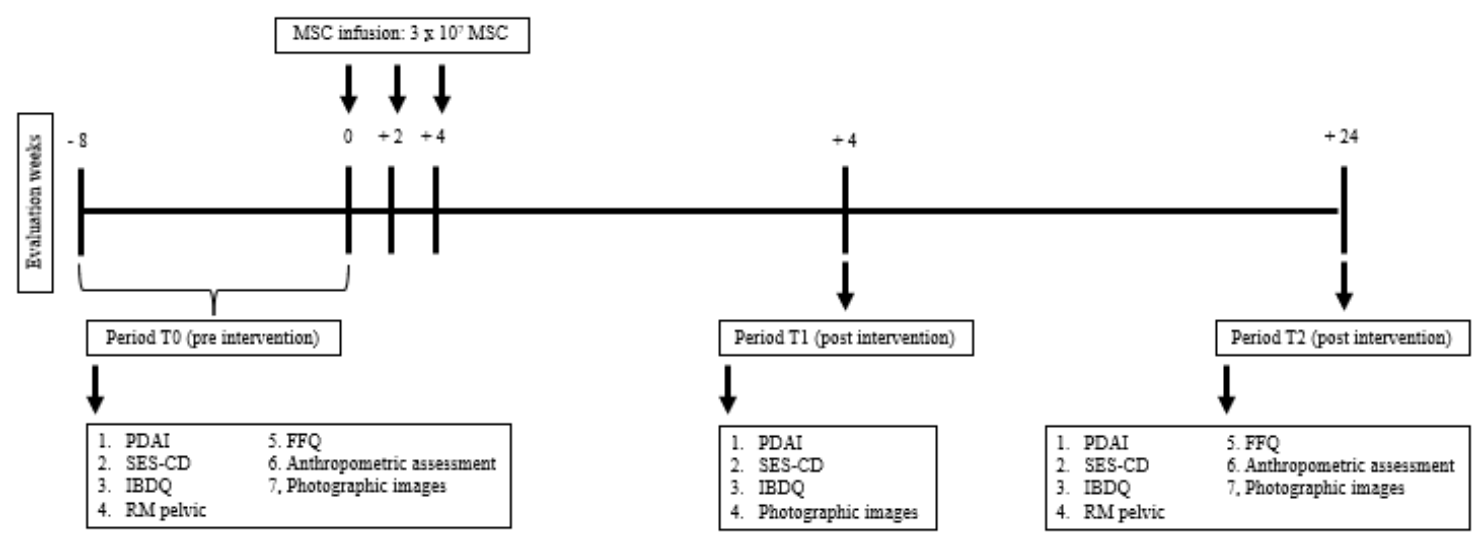

Legend: PDAI = Clinical Perianal Disease Activity Index. SES-CD = CD Simple Endoscopic Score. IBDQ = Quality of Life Questionnaire. RM Pelvic = pelvic magnetic resonance. FFQ = Food Frequency Questionnaire. Source: Authors.

In the period T0, T1 and T2 the Clinical Perianal Disease Activity Index (PDAI) were evaluated (Irvine et al., 1995), the CD Simple Endoscopic Score (SES-CD) (Daperno et al., 2004), quality of life using the Quality of Life Questionnaire (IBDQ) Portuguese-Brazilian version (Pontes et al., 2004), as well as the recording of photographic images of the fistula region. In periods T0 and T2, magnetic resonance imaging of the pelvis was also performed using the Van Assche index (Van Assche et al., 2003), food quality assessment using the Food Frequency Questionnaire (FFQ) for patients with Crohn's disease (Barreto, 2017) adapted according to the Food Guide for the Brazilian Population (Brasil, 2014), assessment of nutritional status, involving the calculation of the body mass index (normal values $=18,5$ a $\left.24,9 \mathrm{~kg} / \mathrm{m}^{2}\right)(\mathrm{WHO}, 1995)$, waist circumference (normal values $=$ men $<94 \mathrm{~cm}$; women $<80 \mathrm{~cm})($ WHO, 1998), arm circumference, with subsequent calculation of its percentage of adequacy (normal values $=90$ a 110\%) (Blackburn, 1979) and analysis of body composition (\% of body fat, \% of skeletal muscle mass and visceral fat) using a bioimpedance scale (model HBF-514C).

\section{Liposuction procedures, isolation and cultivation of adipose-derived stem cells}

The adipose tissue was isolated by the abdominal liposuction procedure performed according to Pesarini et al. (2017). For the processing of each of the three liposuction samples and isolation of ADSCs, collagenase was used for enzymatic digestion, as described by Markarian et al. (2014) with modifications.

The culture medium was Dulbecco's Modified Eagle's Medium (DMEM Sigma®; catalog number D5523-10L) - low glucose, $10 \mathrm{mM}$ HEPES supplemented with $10 \%$ fetal bovine serum (Gibco ${ }^{\mathrm{TM}}$, catalog number 10091148 ) and 1\% antibiotic (Penicillin / Streptomycin, Sigma ${ }^{\circledR}$, A5955). The cells were kept in a humidified incubator with $5 \% \mathrm{CO} 2$ at $37^{\circ} \mathrm{C}$. When cell confluence reached $80-90 \%$, trypsin $(0,25 \%)$ was added to digest the cells and the cell suspension was collected and plaqued into a new culture flask to promove the cell expansion, occurring until the 6th passage (Markarian et al., 2014; Pesarini et al., 2017).

Before being used in infusion procedures, some parameters were analyzed for the clinical use of ADSCs, such as fibroblast-like morphology, absence of pathogen contamination, $>80 \%$ viability, plastic adherence capacity, immunophenotyping characterization and cell differentiation potential, according to the criteria of the International Society for Cell Therapy (Dominici et al., 2006; Robey, 2017). ADSCs were used in the 3rd passage to detect cell phenotype $\left(3 \times 10^{5}\right.$ ADSCs) and the capacity for adipogenic, osteogenic and chondrogenic differentiation ( 1 x $10^{5}$ ADSCs). All materials used for transplantation were previously submitted to cell viability analysis, using trypan blue, and conventional microbiological routine (aerobiosis and microaerophilia), for 72 hours of incubation. 


\section{Praparation of the serynges of adipose-derived stem cells to transplants}

To prepare the syringe to transpant, the ADSCs flasks were first washed with $3 \mathrm{~mL}$ of PBS (3x), then they were trypsinized $(0.25 \%$ trypsin/ $/ 3 \mathrm{~min})$ and the contents were centrifuged $(1200 \mathrm{rpm} / 5 \mathrm{~min})$ in a falcon tube. The supernatant was then discarded and the cell pellet was resuspended in $3 \mathrm{ml}$ PBS. Afterwards, the tubes were centrifuged again (1200rpm/5min). This process was repeated 3x. The pellet of ADSC was diluited in $6 \mathrm{ml}$ of saline solution with a concentration of $1.6 \times 10^{6}$ cells $/ \mathrm{mL}$, and distributed in 2 syringes. This preparation was made, a few hours before each transplant and transported to the room of surgery in a sterile syringe, in a box that kept the temperature between $15-25^{\circ} \mathrm{C}$ to the room of surgery.

The infusions in the fistulas occurred with cells that were in the 4th, 5th and 6th passage. After the 3 procedures of infusions, each patient received a total of $3 \times 10^{7}$ cells.

\section{Fistula preparation and injection procedure}

The injection procedure was made under general anesthesia. First, antisepsis of the perianal region was performed with saline solution, and then the fistulas and their internal and external orifices were carefully located with the aid of probes and saline solution to avoid any type of cytotoxic effect caused by another material. Afterwards, a procedure for debridament of the fistula tracts was performed, through curettage, especially in the internal orifices, with subsequent washing with distilled water to remove the necrotic tissue. After cleaning, the internal openings were closed with simple, absorbable suture, 2-0, and this closure was confirmed by the injection of saline solution through the external opening (Georgiev-Hristov et al., 2018). The ADSCs suspension was evenly injected into the internal orifice and around the fistula wall, taking care not to inject the cells either into the fistula lumen or too far from the fistula wall.

\section{Evaluations}

The safety assessment consisted of monitoring possible adverse events at each study visit. The efficacy evaluation was defined as the closure of external openings that were draining at the beginning of the study (T0), despite mild compression with the fingers, analyzed at week 12 (T1) and at week 24 (T2) after the first infusion with ADSCs. The primary efficacy endpoint was by clinical assessment at each follow-up visit and by pelvic magnetic resonance imaging. Secondary efficacy endpoints included the Perianal Disease Activity Index (PDAI), Inflammatory Bowel Disease Questionnaire (IBDQ) and Simple Endoscopic Score for Crohn's disease (SES-CD).

\section{Results}

Six patients were included in the study, but only three (patients 4, 5 and 6) completed the intervention and follow-up process at 12 and 24 weeks, respectively, because one chose to cancel their participation in the study (patient 1), another presented worsening of the fistulizing disease, requiring colectomy and colostomy (patient 2) and, the third one, did not respond to the ADSCs extraction procedure after three spaced attempts (patient 3). The patients' baseline characteristics were similar (Table 1). 
Table 1 - Characteristics of patients with refractory Crohn's disease at the time of pre-intervention with adipose-derived stem cells.

\begin{tabular}{|c|c|c|c|c|c|c|}
\hline \multirow{2}{*}{ Characteristics } & \multicolumn{6}{|c|}{ Pacients } \\
\hline & 1 & 2 & 3 & 4 & 5 & 6 \\
\hline Age (years) & 26 & 29 & 48 & 31 & 18 & 42 \\
\hline Gender & $\mathrm{M}$ & $\mathrm{F}$ & $\mathrm{M}$ & $\mathrm{M}$ & $\mathrm{F}$ & $\mathrm{M}$ \\
\hline Duration of disease (years) & 1 & 21 & 14 & 4 & 3 & 2 \\
\hline Family history of IBD & No & No & Não & Yes & No & No \\
\hline Was a smoker & No & No & Yes & No & No & Yes \\
\hline Current smoker & No & No & Yes & No & No & Yes \\
\hline Smoking time (years) & 0 & 0 & 36 & 0 & 0 & 25 \\
\hline Previous surgeries & $\begin{array}{l}\text { Curettage and } \\
\text { seton }\end{array}$ & $\begin{array}{l}\text { Curettage and } \\
\text { seton }\end{array}$ & $\begin{array}{l}\text { Curettage, seton and } \\
\text { fistulectomy }\end{array}$ & $\begin{array}{l}\text { Curettage, seton, } \\
\text { fistulectomy and } \\
\text { hemorrhoidectomy }\end{array}$ & Curettage and seton & $\begin{array}{l}\text { Curettage, seton and } \\
\text { fibrina glue }\end{array}$ \\
\hline $\begin{array}{c}\text { Previous } \\
\text { biological/immunomodulatory } \\
\text { therapy }\end{array}$ & AZA & $\begin{array}{l}\text { AZA, MES, } \\
\text { ADA }\end{array}$ & $\begin{array}{l}\text { IFX, CIPR, MTX, } \\
\text { ADA, ranitidina, } \\
\text { tramadol }\end{array}$ & IFX, ADA & $\begin{array}{l}\text { AZA, MES, IFX, } \\
\text { CIPR, MTX, USTE }\end{array}$ & $\begin{array}{l}\text { AZA, COR, IFX, CIPR, } \\
\text { ranitidina, omeprazol }\end{array}$ \\
\hline $\begin{array}{c}\text { Previous } \\
\text { biological/immunomodulatory } \\
\text { therapy during the study }\end{array}$ & $\mathrm{AZA}, \mathrm{ADA}$ & AZA, MES & HI & USTE & $\begin{array}{l}\text { AZA, CIPR, MTX, } \\
\text { dipirona, tramadol }\end{array}$ & $\begin{array}{l}\text { IFX, morfina, ATP, } \\
\text { GABA }\end{array}$ \\
\hline \multicolumn{7}{|l|}{ Montreal Classification } \\
\hline Age at which diagnosis was established & A2 & $\mathrm{A} 2$ & $\mathrm{~A} 2$ & A2 & A1 & A2 \\
\hline $\begin{array}{c}\text { Anatomical location of greatest extent of } \\
\text { the disease }\end{array}$ & L3 & L3 & L3 & L1 & L3 & L3 \\
\hline Clinical behavior of the disease & $\begin{array}{l}\text { B3 + concomitant } \\
\text { perianal disease }\end{array}$ & $\begin{array}{c}\mathrm{B} 3+\text { concomitant } \\
\text { perianal disease }\end{array}$ & $\begin{array}{c}\mathrm{B} 3+\text { concomitant } \\
\text { perianal disease }\end{array}$ & $\begin{array}{l}\text { B3 + concomitant } \\
\text { perianal disease }\end{array}$ & $\begin{array}{l}\mathrm{B} 3+\text { concomitant } \\
\text { perianal disease }\end{array}$ & $\begin{array}{l}\text { B3 + concomitant } \\
\text { perianal disease }\end{array}$ \\
\hline Number fístulas & 2 & 2 & 2 & 3 & 4 & 2 \\
\hline Type of fistula & Perianal & Perianal & Perianal & Perianal & Perianal & Perianal \\
\hline
\end{tabular}

Legend: $\mathrm{IBD}=$ inflammatory bowel disease. $\mathrm{M}=$ male. $\mathrm{F}=$ female. $\mathrm{A} 2=17$ to 40 years. $\mathrm{A} 1=\leq 16$ years. $\mathrm{L} 1=$ terminal ileum. $\mathrm{L} 3=\mathrm{ileum}$ and colon. $\mathrm{B} 3=$ penetrating disease. $\mathrm{AZA}=$ azathioprine. $\mathrm{IFX}=$ infliximab. ADA = adalunimab. MES = mesalazine. $\mathrm{CIPR}=$ ciprofloxacin. USTE $=$ ustekinumab. MTX = metronidazole. HI $=$ human insulin. $\mathrm{COR}=$ corticoid. $\mathrm{ATP}=$ amitriptyline. GABA = gabapentin. Source: Authors. 
The ADSCs showed spindle-like morphology (Figure 2A), expressed the cell surface antigens CD90 and CD105, and showed low expression of CD133 and CD34 (Figure 2B). The cells used in this study had the capacity to differentiate into adipogenic, osteogenic and chondrogenic cells, which were confirmed by Oil red O, Alizarin red S and Alcian Blue stains.

Figure 2 - Morphology, characterization and differentiation potential of adipose-derived stem cells (ADSCs) derived from adipose tissue. ADSCs similar to fibroblasts in the process of expansion (A1) and with 80 to $90 \%$ cell confluence (A2). MSC immunophenotypic profile (B). The cells expressed the markers CD 90 and CD 105 and did not express CD 133 and CD 34. Photomicrographs of undifferentiated ADSCs cultures with fibroblastoid appearance (C); adipogenic differentiation confirmed by Oil Red staining (D); osteogenic differentiation confirmed by Alizarin Red staining (E); and chondrogenic differentiation confirmed by Alcian Blue staining (F) (magnification 400x).

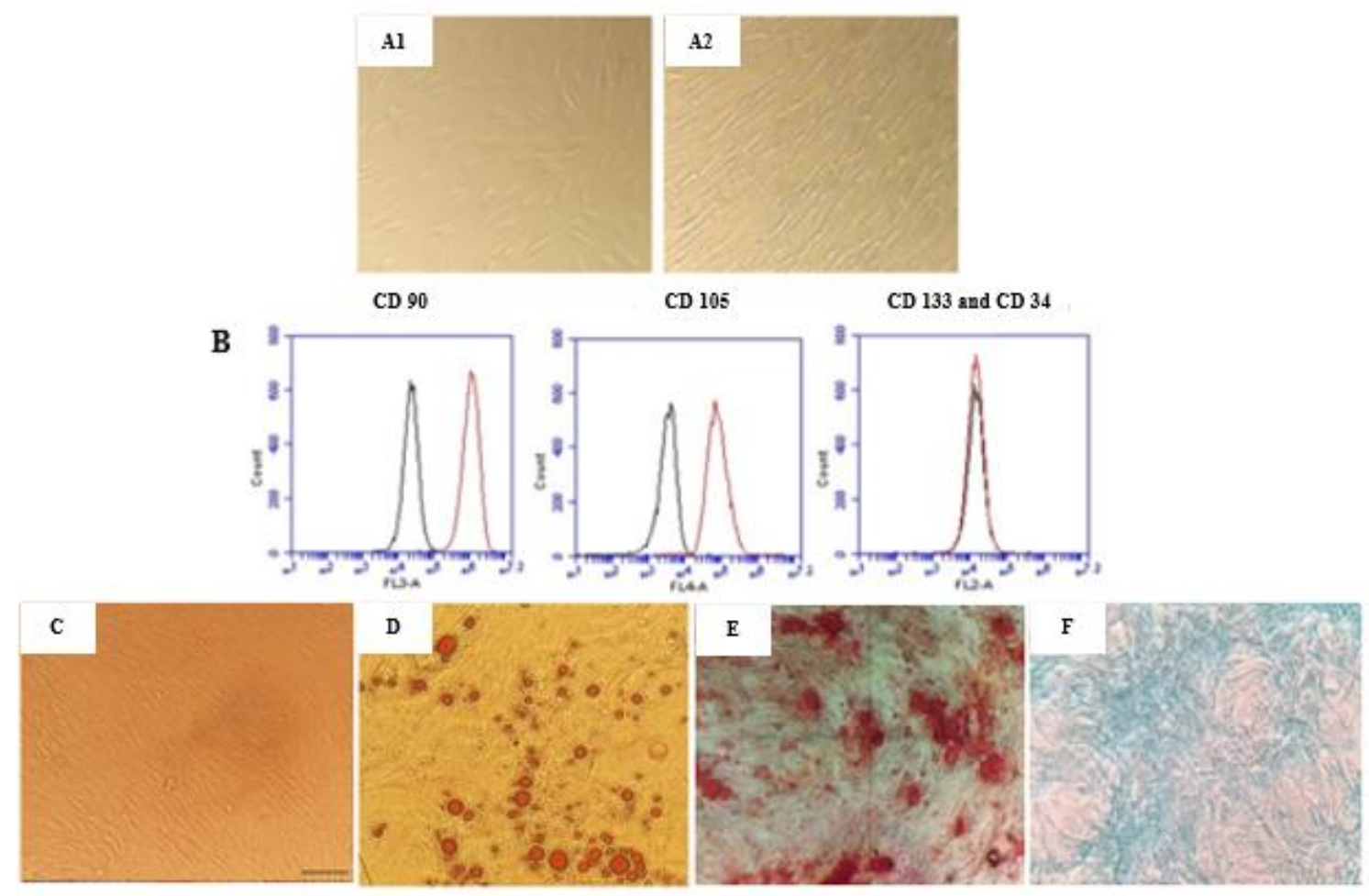

Source: Authors.

\section{Pacient 4}

The patient had 3 perianal fistulas in the T0 period. Regarding the primary outcome of treatment efficacy, the closure of the external opening of a fistula in the T1 period was noted, but the worsening of the Van Assche index at the end of the 24 weeks of follow-up, indicating that the fistula tracts and the inflammatory process internal persists on pelvic MRI images. The PDAI index decreased at week 12 and remained satisfactory throughout the 24 weeks of follow-up, and this decrease was associated with improved quality of life until the end of the study in all domains analyzed by the IBDQ. However, it is noteworthy that the emotional subdomain showed the lowest progression, especially at the end of the study. Luminal DC activity remained as endoscopically active disease throughout follow-up, increasing from 4 to a score of 10 (Table 2). Also, improvement of the epithelium surrounding the perianal region was observed, with local re-epithelialization, as well as healing of the external opening of the fistula that closed, reduction of edema and secretions in the region of the fistulas, comparing the pre and postintervention periods (Figure $3 \mathrm{~A}, \mathrm{D}$ and $\mathrm{G}$ ). 
No relevant changes were observed in anthropometric measurements of weight, arm circumference, waist circumference, percentage of body fat and visceral fat during the 24 weeks of follow-up. However, the overweight classification reached at the end of the follow-up period and the slight difference between the current weight and the usual reported weight are evidenced, indicating the weight loss by the patient after the diagnosis of the disease. The percentage of skeletal muscle mass remained high throughout the period (Table 3).

As for the quality of food, the food groups that showed an increase in daily and/or weekly consumption in the 24th week were: meat and eggs group, fruit and roots and tubers group, while the others remained with low consumption in these frequencies, mainly the milk and cheese group, the beans group and, positively, the alcoholic beverages and ultra-processed foods group (Table 4).

\section{Pacient 5}

The patient had 3 perianal fistulas in the T0 period. The patient presented closure of the external openings of 2 fistulas in the T2 period, with an improvement in the Van Assche index at the end of the 24 weeks of follow-up. The PDAI score showed a reduction until the end of the study period, indicating an improvement. Quality of life improved six months after the first infusion with the ADSCs, however, the emotional subdomain showed a worsening of its score after 12 and 24 weeks of followup (Table 2). Luminal DC activity changed from endoscopically active to inactive disease over the course of follow-up, decreasing from 5 to a score of 0 (Table 2). The improvement of the epithelium surrounding the perianal region, with local reepithelialization, as well as the healing of the external opening of the fistula that closed, reduction of edema and secretions in the region of the fistulas, can be observed in the pre- and post-intervention periods (Figure $3 \mathrm{~B}, \mathrm{E}$ and H).

Most of the anthropometric measurements performed were adequate during the follow-up period, with the exception of arm circumference, at the 24th week, which indicated mild malnutrition. In addition, the percentage of skeletal muscle mass remained high throughout the period (Table 3).

The assessment of food frequency indicated that daily and/or weekly consumption did not increase proportionally for any group. However, there is a positive decrease in consumption, in these frequencies, of foods from the saturated and ultraprocessed fat groups, but also, negatively, of unsaturated fats, cereals, fruits, milk and cheese and the beans group (Table 4).

\section{Pacient 6}

The patient had 2 perianal fistulas in the T0 period. In period T1, there was the closure of the external opening of a fistula, which remained in period T2; however, there was no decrease in the Van Assche index, which increased 4 points in relation to T0. The PDAI score decreased from 20 at baseline to 18, remaining like this in the T1 and $\mathrm{T} 2$ periods, and this decrease was accompanied by an improvement in quality of life, although the emotional subdomain has not evolved. Luminal DC activity remained stable throughout the study, with a score of 0 , indicating endoscopically inactive disease (Table 2). The patient also showed improvement in the epithelium surrounding the perianal region, with healing and re-epithelialization of the external opening of the fistula that closed, decreased edema and secretions in the fistula region, comparing the pre- and postintervention periods (Figure $3 \mathrm{C}, \mathrm{F}$ and I).

The patient's weight loss is evident, due to the difference between the current weight and the usual weight reported, which may be related to the diagnosis of the disease. In addition, most anthropometric measurements were inadequate during the follow-up period, highlighting excess body fat and low percentage of skeletal muscle mass (Table 3).

Assessing the quality of food in the 24th week, there was an increase in daily and/or weekly consumption for foods from the groups of milk and cheese, saturated and unsaturated fats, cereals, fruits, alcoholic beverages, water and teas and for ultra-processed foods. While the foods that remain low in consumption are the group of beans and roots and tubers (Table 4). 
Research, Society and Development, v. 11, n. 1, e57511125299, 2022

(CC BY 4.0) | ISSN 2525-3409 | DOI: http://dx.doi.org/10.33448/rsd-v11i1.25299

Table 2 - Characteristics of Crohn's disease in patients pre- and post-intervention with adipose-derived stem cells.

\begin{tabular}{|c|c|c|c|c|}
\hline \multirow{2}{*}{ Characteristics of disease } & \multirow{2}{*}{ Pacient } & \multicolumn{3}{|c|}{ Study period } \\
\hline & & T0 & T1 & T2 \\
\hline \multirow{3}{*}{ PDAI } & 4 & 20 & 13 & 15 \\
\hline & 5 & 22 & 17 & 18 \\
\hline & 6 & 20 & 18 & 18 \\
\hline \multirow{3}{*}{ IBDQ } & 4 & 94 & 123 & 116 \\
\hline & 5 & 84 & 103 & 112 \\
\hline & 6 & 55 & 72 & 110 \\
\hline \multirow{3}{*}{ Van Assche index } & 4 & 11 & NR & 17 \\
\hline & 5 & 15 & NR & 9 \\
\hline & 6 & 15 & NR & 19 \\
\hline \multirow{3}{*}{ SES-CD } & 4 & 4 & NR & 10 \\
\hline & 5 & 5 & NR & 0 \\
\hline & 6 & 0 & NR & 0 \\
\hline \multirow{3}{*}{ Number of perianal fistulas } & 4 & 3 & 2 & 4 \\
\hline & 5 & 3 & 3 & 1 \\
\hline & 6 & 2 & 1 & 1 \\
\hline \multirow{3}{*}{ Number of perianal fistulas closed } & 4 & 0 & 1 & 0 \\
\hline & 5 & 0 & 0 & 2 \\
\hline & 6 & 0 & 1 & 0 \\
\hline
\end{tabular}

Legend: PDAI = Perianal Disease Activity Index; IBDQ = Inflammatory Bowel Disease Questionnaire; SES-CD = Simple Endoscopic Score for Crohn's; T0 = pre-intervention with adipose-derived stem cells; T1 = 3 months post-intervention with adipose-derived stem cells; T2 $=6$ months post-intervention with adipose-derived stem cells; NR $=$ not rated. Source: Authors. 
Figure 3 - Representation of the evolution of the healing process of perianal fistulas after local injections of stem cells derived from adipose tissue at the time of the first injection (AC), 12 weeks after the first injection (DF) and 24 weeks after the first injection (GI). In detail, patients 4,5 and 6 independently improved the perianal inflammatory process, with an evident decrease in edema, appearance of regenerative tissue in this region and closure of some external openings (24th week). This last criterion observed mainly in patients 5 and 6.

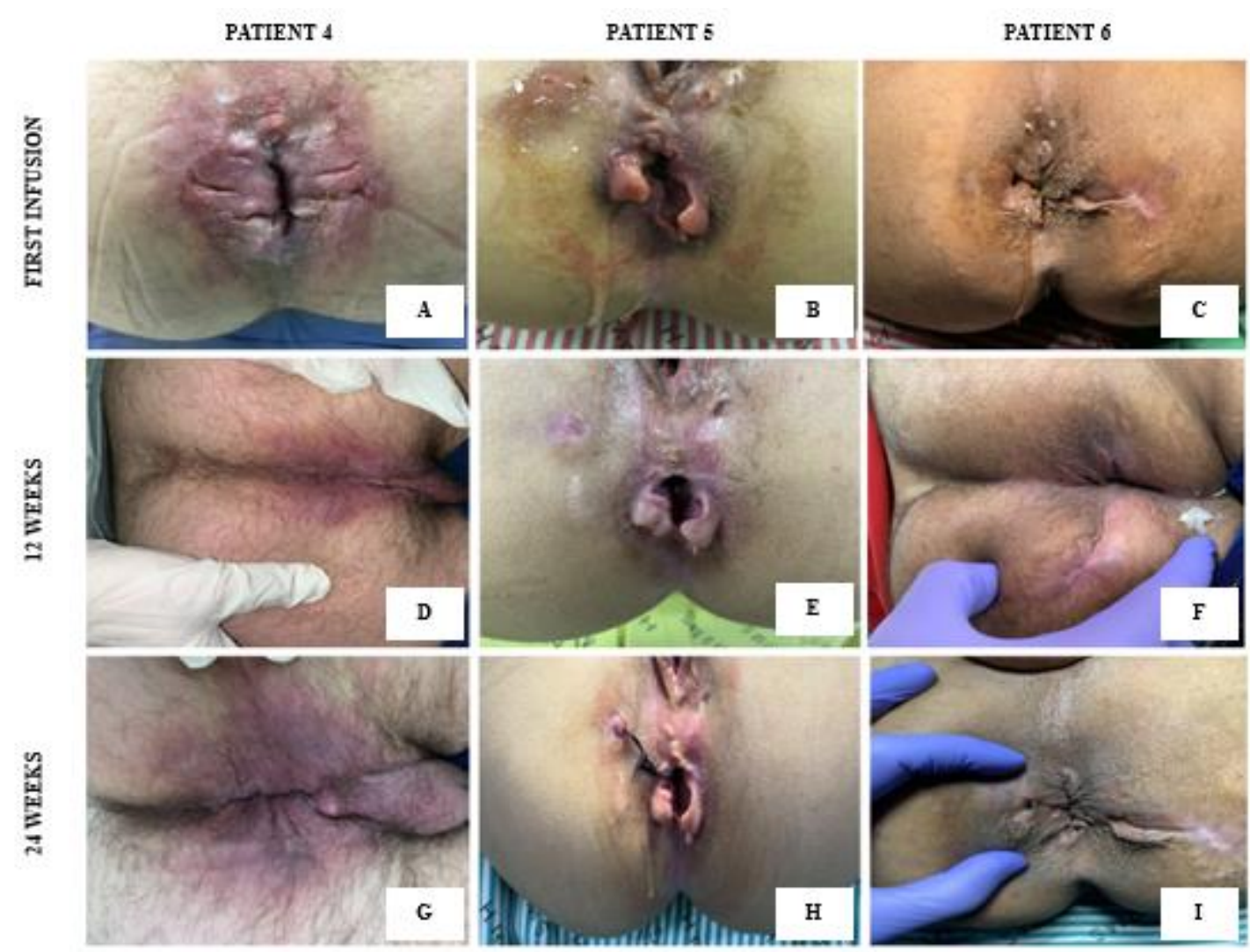

Source: Authors. 
Table 3 - Anthropometric characteristics of patients at pre-intervention (T0) and six months after intervention (T2) with adiposederived stem cells.

\begin{tabular}{|c|c|c|c|c|c|}
\hline \multirow{2}{*}{$\begin{array}{l}\text { Anthropometric } \\
\text { Characteristics }\end{array}$} & \multirow{2}{*}{ Pacient } & \multicolumn{2}{|c|}{ Study period } & \multicolumn{2}{|c|}{ Classification } \\
\hline & & T0 & T2 & T0 & $\mathbf{T 2}$ \\
\hline \multirow{3}{*}{ UW (kg) } & 4 & 74 & NR & $\mathrm{sc}$ & $\mathrm{sc}$ \\
\hline & 5 & 54 & NR & $\mathrm{sc}$ & $\mathrm{sc}$ \\
\hline & 6 & 94 & NR & $\mathrm{sc}$ & $\mathrm{sc}$ \\
\hline \multirow{3}{*}{$\mathrm{CW}(\mathrm{kg})$} & 4 & 70,4 & 73,9 & $\mathrm{sc}$ & $\mathrm{sc}$ \\
\hline & 5 & 54,2 & 56,9 & $\mathrm{sc}$ & $\mathrm{sc}$ \\
\hline & 6 & 89,2 & 84,4 & $\mathrm{sc}$ & $\mathrm{sc}$ \\
\hline \multirow{3}{*}{ BMI $\left(\mathrm{kg} / \mathrm{m}^{2}\right)$} & 4 & 24 & 25 & Eutrophy & Overweight \\
\hline & 5 & 21 & 22 & Eutrophy & Eutrophy \\
\hline & 6 & 33,0 & 31,0 & Obesity I & Obesity I \\
\hline \multirow{3}{*}{$\mathrm{AC}(\mathrm{cm})$} & 4 & 33 & 35 & Eutrophy & Eutrophy \\
\hline & 5 & 24 & 23,5 & Eutrophy & Mild malnutrition \\
\hline & 6 & 32 & 34 & Eutrophy & Eutrophy \\
\hline \multirow{3}{*}{$\mathrm{WC}(\mathrm{cm})$} & 4 & 78 & 81 & Adequate & Adequate \\
\hline & 5 & 58 & 69 & Adequate & Adequate \\
\hline & 6 & 110 & 105 & Very high & Very high \\
\hline \multirow{3}{*}{ EMM (\%) } & 4 & 44,9 & 44,6 & Very high & Very high \\
\hline & 5 & 31 & 31,3 & High & High \\
\hline & 6 & 27,3 & 26,2 & Low & Low \\
\hline \multirow{3}{*}{$\mathrm{BF}(\%)$} & 4 & 11,9 & 11,3 & Adequate & Adequate \\
\hline & 5 & 26 & 28 & Adequate & Adequate \\
\hline & 6 & 39,6 & 39,3 & Very high & Very high \\
\hline \multirow{3}{*}{ GV } & 4 & 8 & 7 & Adequate & Adequate \\
\hline & 5 & 3 & 3 & Adequate & Adequate \\
\hline & 6 & 18 & 19 & Very high & Very high \\
\hline
\end{tabular}

Legend: $\mathrm{UW}=$ Usual weight $\mathrm{CW}=$ Current weight $\mathrm{IMC}=$ Body Mass Index; $\mathrm{AC}=$ arm circumference; $\mathrm{WC}=$ waist circumference; $\mathrm{EMM}=$ skeletal muscle mass; $\mathrm{BF}=$ Body Fat; $\mathrm{VF}=$ Visceral Fat; $\mathrm{NR}=$ not rated; $\mathrm{cm}=$ centimeters; $\mathrm{T} 0=$ pre-intervention with adipose-derived stem cells; T2 $=6$ months post-intervention with adipose-derived stem cells. Source: Authors. 
Research, Society and Development, v. 11, n. 1, e57511125299, 2022

(CC BY 4.0) | ISSN 2525-3409 | DOI: http://dx.doi.org/10.33448/rsd-v11i1.25299

Table 4 - Frequency of food consumption of patients in the moments of pre-intervention (T0) and six months after the intervention (T2) with adipose-derived stem cells.

\begin{tabular}{|c|c|c|c|c|c|c|c|c|c|c|c|c|c|c|}
\hline \multirow{3}{*}{ Group of foods } & \multirow{3}{*}{ Study period } & \multicolumn{12}{|c|}{ Frequency of consumption } & \multirow{3}{*}{$\begin{array}{l}\mathbf{n}^{\mathbf{o}} \text { of foods } \\
\text { evaluated }\end{array}$} \\
\hline & & \multicolumn{4}{|c|}{ Pacient 4} & \multicolumn{4}{|c|}{ Pacient 5} & \multicolumn{4}{|c|}{ Pacient 6} & \\
\hline & & N.C & D.F. & W.F. & M.F. & N.C & D.F. & W.F. & M.F. & N.C & D.F. & W.F. & M.F. & \\
\hline \multirow{2}{*}{ Milk and cheese } & T0 & 7 & 0 & 0 & 0 & 4 & 2 & 0 & 1 & 4 & 0 & 0 & 3 & \multirow{2}{*}{7} \\
\hline & $\mathrm{T} 2$ & 7 & 0 & 0 & 0 & 4 & 0 & 2 & 1 & 1 & 1 & 2 & 3 & \\
\hline \multirow{2}{*}{ Saturated fat } & T0 & 4 & 0 & 1 & 1 & 3 & 2 & 0 & 1 & 2 & 1 & 1 & 2 & \multirow{2}{*}{6} \\
\hline & $\mathrm{T} 2$ & 5 & 0 & 1 & 0 & 5 & 0 & 0 & 1 & 0 & 0 & 6 & 0 & \\
\hline \multirow{2}{*}{ Meat and eggs } & T0 & 4 & 2 & 1 & 0 & 3 & 2 & 1 & 1 & 2 & 3 & 1 & 1 & \multirow{2}{*}{7} \\
\hline & $\mathrm{T} 2$ & 3 & 3 & 0 & 1 & 4 & 0 & 3 & 0 & 1 & 3 & 1 & 2 & \\
\hline \multirow{2}{*}{ Unsaturated fat } & T0 & 3 & 0 & 0 & 3 & 1 & 4 & 0 & 1 & 5 & 1 & 0 & 0 & \multirow{2}{*}{6} \\
\hline & $\mathrm{T} 2$ & 4 & 0 & 1 & 1 & 1 & 1 & 2 & 2 & 0 & 3 & 0 & 3 & \\
\hline \multirow{2}{*}{ Beans } & T0 & 1 & 0 & 0 & 1 & 2 & 0 & 0 & 0 & 1 & 0 & 1 & 0 & \multirow{2}{*}{2} \\
\hline & $\mathrm{T} 2$ & 2 & 0 & 0 & 0 & 2 & 0 & 0 & 0 & 1 & 0 & 0 & 1 & \\
\hline \multirow{2}{*}{ Cereals } & T0 & 8 & 3 & 0 & 3 & 6 & 6 & 2 & 0 & 7 & 1 & 1 & 5 & \multirow{2}{*}{14} \\
\hline & $\mathrm{T} 2$ & 8 & 0 & 4 & 2 & 8 & 3 & 2 & 1 & 5 & 4 & 3 & 2 & \\
\hline \multirow{2}{*}{ Fruits } & T0 & 17 & 1 & 0 & 1 & 5 & 10 & 4 & 0 & 15 & 0 & 2 & 2 & \multirow{2}{*}{19} \\
\hline & $\mathrm{T} 2$ & 7 & 1 & 1 & 10 & 9 & 4 & 2 & 4 & 4 & 0 & 6 & 9 & \\
\hline \multirow{2}{*}{ Roots and tubers } & T0 & 3 & 0 & 1 & 1 & 2 & 3 & 0 & 0 & 2 & 0 & 3 & 0 & \multirow{2}{*}{5} \\
\hline & $\mathrm{T} 2$ & 4 & 1 & 0 & 0 & 2 & 3 & 0 & 0 & 1 & 0 & 2 & 2 & \\
\hline \multirow{2}{*}{ Legumes e vegetables } & T0 & 19 & 2 & 0 & 3 & 11 & 13 & 0 & 0 & 13 & 11 & 0 & 0 & \multirow{2}{*}{24} \\
\hline & $\mathrm{T} 2$ & 12 & 0 & 4 & 8 & 10 & 9 & 3 & 2 & 5 & 7 & 5 & 7 & \\
\hline \multirow{2}{*}{ Alcoholic beverages } & T0 & 1 & 0 & 0 & 2 & 3 & 0 & 0 & 0 & 3 & 0 & 0 & 0 & \multirow{2}{*}{3} \\
\hline & $\mathrm{T} 2$ & 1 & 0 & 0 & 2 & 3 & 0 & 0 & 0 & 0 & 1 & 2 & 0 & \\
\hline \multirow{2}{*}{ Water and teas } & T0 & 3 & 2 & 0 & 0 & 3 & 2 & 0 & 0 & 5 & 1 & 0 & 0 & \\
\hline & $\mathrm{T} 2$ & 3 & 2 & 0 & 0 & 3 & 2 & 0 & 0 & 0 & 2 & 1 & 2 & 5 \\
\hline & T0 & 22 & 0 & 1 & 3 & 4 & 14 & 8 & 0 & 13 & 4 & 4 & 4 & \\
\hline Ultra-processad & $\mathrm{T} 2$ & 21 & 0 & 1 & 4 & 14 & 0 & 10 & 2 & 6 & 10 & 2 & 6 & 26 \\
\hline
\end{tabular}

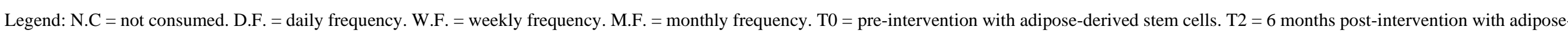
derived stem cells. Source: Authors. 


\section{Security assessment}

During the study period, the following adverse events were observed: perianal pain, increased inflammatory secretions, perianal edema, fever, constipation, diarrhea, decreased food intake and hair loss related to complications of the disease; moderate pain at the liposuction site, which was associated with fat collection and was quickly resolved by simple oral analgesia (with paracetamol and tramadol); and no relevant side effects associated with ADSC infusion were observed, the most common being pain and edema in the perianal region and fever, the latter only in patient 5 , all occurring a few hours after cell administration.

\section{Discussion}

Perianal fistulas are a common complication of $\mathrm{CD}$, and it is estimated that it can affect about a third of patients during the course of the disease (Ingle \& Loftus, 2007), besides that, $40 \%$ of them can develop this, even after complex surgeries and advanced medical therapy (Bislenghi et al., 2019). The treatment of fistulizing CD has changed a lot in the last decade, and with the increased of regenerative medicine, based primarily on cell therapy, a promising approach to treat it effectively and with reduced side effects has been provided (Lightner \& Faubion, 2017). Thus, this study evidence that the process of local injection of autologous ADSCs it is safe, since few adverse effects were related and observed after the infusions. Other similar studies also does not present significant adverse effects (Ciccocioppo et al., 2011; Zhou et al., 2020).

The mechanisms of action by which ADSCs infusion act in this particularly condition, it is still unclear in the literature (Lightner \& Faubion, 2017; Carvello et al., 2019), Our results presents after three ADSCs infusions, the healing process of the epithelium that surrounds the perianal region, the closure of some fistulas, the re-epithelialization of the external perianal region, the reduction of secretions, pain and the degree of induration in this region, the endoscopic improvement at the level of large intestine (patients 5 and 6) and the PDAI index, as well as the decrease in the Van Assche index (patient 5), may be based, possibly, on the effects of tissue repair, immunomodulatory and anti-inflammatory of these cells (Carvello et al., 2019). Even so, it is still necessary a bigger investigation in relation to the action of ADSCs and a follow-up time to better analyze the effectiveness of the treatment with ADSCs.

After the application of stem cells, it have the capacity to differentiate into other cell types and engraft in other tissues (Cashman et al., 2013), also can enxert a trophic action on the damaged tissue, limit apoptosis of local cells, recruit immune cells to the injury site, reduce fibrosis in the damaged organ, stimulate angiogenesis (Kachgal \& Putnam, 2011), modulate the healing process by stimulating dermal fibroblasts and neocollagen (Kim et al, 2007). In addition, the reduction and control of inflammation in the perianal region may be related to their ability to establish cell-to-cell contact, enabling the reduction in the proliferation of immune cells (Podojil et al., 2009), altered maturation of antigen-presenting cells, decreased secretion of proinflammatory cytokines (Aggarwal \& Pittenger, 2005) and promoting the recruitment and generation of regulatory $\mathrm{T}$ cells (Ciccocioppo et al., 2011). This becomes important, since immunological imbalance is characteristic of CD and is related to several symptoms (Carvello et al., 2019).

In relation that the indicators that did not improve in some patients during the transplant period, was raised the hypothesis that the intense inflammatory process present, especially in the perianal region, could not be effectively controlled. It could result in a failure in closure of some fistulas, even if patients continued to use medication during the intervention (Table 1). In addition, it is believed that in this study a lower total concentration of ADSCs ( $\left.3 \times 10^{7} \mathrm{ADSCs}\right)$ was used, it can be justify as no growth factors other than FBS were used during cell culture. This addition of grow factors is observed in the methodology of other studies that used a higher number of ADSCs in their treatments (Cho et al., 2015). However, as one of the objectives of this study was to assess safety, it was decided to work with lower doses and administered interspersed ( $\left.1 \times 10^{7} \mathrm{ADSCs} / \mathrm{infusion}\right)$, 
In this study, other treatment efficacy points were analyzed. Patient 5 showed an improvement in the SES-CD score and, it is assumed that this can be understood both by the capacity that this cell type has to migrate towards other lesion sites (Karp \& Teo, 2009), being able to exert its benefits at the intestinal level even if infused in the fistula region; as for the possible combined action of the cells with the drug therapy used during the treatment period. Thus, in vitro tests and in humans, when they are infused intravenously (Kagramanova et al., 2016), mesenchymal stem cells have their immunomodulatory effects increased when combined with pharmacological therapy for $\mathrm{CD}$, when compared to treatment involving only the cells.

Another point observed was the positive impact that infusions with ADSCs had on the quality of life of patients. However, among the domains analyzed by the IBDQ, the emotional had the worst evolution throughout the study. Problems such as anxiety and depression, highly prevalent in IBD, are associated with poorer health-related quality of life for these individuals (Choi et al., 2019). This psychological stress may be related to the patients' own awareness of their chronic and relapsing diagnosis (Choi et al., 2019), but also with the possible expectation generated by the intervention proposed in this research, which may make them anxious or depressed and, with that, even cause the exacerbation of the disease (Cho et al., 2015), making it impossible for some indicators evaluated to improve further.

Among the patients evaluated, most anthropometric measurements were adequate, but due to the small number of participants, it is difficult to establish the nutritional diagnosis of the sample. In any case, the high percentage of MME in patients 4 and 5 should be pointed out, which is not consistent with other studies that found muscle mass depletion in CD (Rocha et al., 2009). Thus, it was expected to obtain, from the anthropometric measurements analyzed, the state of malnutrition among the three patients, since the literature indicates the high risk of this population for this condition (Bischoff et al., 2020). However, excess weight and body fat in patients 4 and 5, respectively, may reflect the change in the nutritional scenario in IBD, which is the increase in the number of cases of overweight and obesity among them (De Castro et al., 2019), it is no longer marked only by low weight, which is mainly due to an increasingly westernized lifestyle, with high-calorie diets, increased sedentary lifestyle and predisposing genetic risk factors (Kreuter et al., 2019).

The assessment of dietary pattern in CD is important, as there are few data in the literature on this. Through patient reports, the difficulty in maintaining a varied diet was noted, especially during times of disease activity. The foods that had low consumption throughout the study, in accordance for the three evaluated, were those that belong to the group of beans. Also, other foods that maintained low consumption were mentioned, such as those from the groups of milk and cheese, ultra-processed products, cereals, roots and tubers, fats and alcoholic beverages. Although it has not been determined which experiences led the patients to have low food intake, many of the foods mentioned are consistent with other studies (De Castro et al., 2020) as items that worsen the symptoms related to the disease, and because of that, they are less ingested.

This research was interrupted before its completion due to the Sars-Cov-2 pandemic, thus justifying the reduced number of patients and only 6 months of follow-up. However, its importance should be emphasized because this is the first survey conducted at the national level, that evaluates the use of ADSCs in refractory perianal fistulas of patients with CD treated in public hospitals, and that its realization promotes the encouragement of other researches seeking to improve this disease.

\section{Conclusion}

In conclusion, the data suggest that the injection of autologous ADSCs is possible and well tolerated. Furthermore, their application has been shown to produce clinical benefits for this group of patients, and improve their quality of life, with the potential to treat perianal fistulas in $\mathrm{CD}$, which encourages further studies.

Thus, it is suggested that future studies evaluate the efficacy and safety of autologous ADSC transplantation in a larger group of patients, as well as for a longer follow-up period. Furthermore, the analysis of a dietary intervention together with cell transplantation may be beneficial and valid for patients with perianal fistulas in Crohn's disease (CD). 


\section{References}

Aguilera-Castro, L., Ferre-Aracil, C., Garcia-Garcia-De-Paredes, A., Rodriguez-De-Santiago, E., \& Lopez-Sanroman, A (2017). Management of complex perianal Crohn's disease. Annals of Gastroenterology, 30 (1), 33-44.

Aggarwal, S., \& Pittenger, M. F. (2005). Human mesenchymal stem cells modulate allogeneic immune cell responses. Blood, 105 (4), $1815-1822$.

Avivar-Valderas, A., Martín-Martín, C., Ramírez, C., Del Río, B., Menta R., Mancheño-Corvo, P et al (2019). Dissecting Allo-Sensitization After Local Administration of Human Allogeneic Adipose Mesenchymal Stem Cells in Perianal Fistulas of Crohn's Disease Patients. Frontiers in Immunology, 14 (10), 1244

Almeida Filho, N., \& Rouquayrol, Z. Methodological foundations of epidemiology. In: Almeida Filho, N., Barreto, ML (Org.). Epidemiology and health: fundamentals, methods and applications. 9. ed. São Paulo: Medsi, 2011.

Barreto, L. M. R. (2017). Avaliação da densidade mineral óssea e da composição corporal em portadores de doença de Crohn. [Dissertação]. Universidade Estadual de Campinas, Faculdade de Ciências Médicas, Campinas, SP.

Bislenghi, G., Wolthuis, A., Van Assche, G., Vermeire, S., Ferrante, M., \& D'hoore, A (2019). Cx601 (darvadstrocel) for the treatment of perianal fistulizing Crohn's disease. Expert Opinion on Biological Therapy, 19 (7), 607-616.

Bischoff, SC., Escher, J., Hébuterne, X., Klek, S., Krznaric, Z., Schneider, S et al (2020). ESPEN practical guideline: Clinical Nutrition in inflammatory bowel disease. Clinical Nutrition, 39, 632-653.

Blackburn, G. L., \& Thornton, P. A (1979). Nutritional assessment of the hospitalized patients. Medical Clinics of North America, 63, $1103-115$.

Carvello, M., Lightner, A., Yamamoto, T., Kotze, P. G., \& Spinelli, A. (2019). Mesenchymal Stem Cells for Perianal Crohn's Disease. Cells, 8 (7), 764.

Cashman, T. J., Gouon-Evans, V., \& Costa, K. D. (2013). Mesenchymal stem cells for cardiac therapy: practical challenges and potential mechanisms. Stem Cell Reviews and Reports, 9 (3), 254-265.

Cho, Y. B., Park, K. J., Yoon, S. N., Song, K. H., Kim, D. S., Jung, S. H., et al (2015). Long-Term Results of Adipose-Derived Stem Cell Therapy for the Treatment of Crohn's Fistula. Stem Cells Translational Medicine, 4 (5), 532-537.

Choi, K., Chun, J., Han, K., Park, S., Soh, H., Kim, J et al (2019). Risk of anxiety and depression in patients with inflammatory bowel disease: a national population-based study. Journal of Clinical Medicine, 8 (5), 654.

Ciccocioppo, R., Bernardo, M. E., Sgarella, A., Maccario, R., Avanzini, M. A., Ubezio, C et al (2011). Autologous bone marrow-derived mesenchymal stromal cells in the treatment of fistulising Crohn's disease. Gut, 60 (6), 788-798.

Daperno, M., D'haens, G., Van Assche, G., Baert, F., Bulois, P., Maunoury, V et al (2004). Development and validation of a new, simplified endoscopic activity score for Crohn's disease: the SES-CD. Gastrointest Endoscopy, 60, 505-12.

De Castro, M. M., Corona, L. P., Pascoal, L. B., Rodrigues, B. L., Ayrizono, M. L. S., Coy, C. S. R., et al (2019). Impaired nutritional status in outpatients in remission or with active Crohn's disease - classified by objective endoscopic and imaging assessments. Clinical Nutrition ESPEN, 33, 60-65.

De Castro, M. M., Corona, L. P., Pascoal, L. B., Miyamoto, J. E., Ignacio-Souza, L. M., Ayrizono, M. L. S., et al (2020). Dietary Patterns Associated to Clinical Aspects in Crohn's Disease Patients. Scientific Reports, 10, 7033.

Dominici, M., Le Blanc, K., Mueller, I et al (2006). Minimal criteria for defining multipotent mesenchymal stromal cells. The International Society for Cellular Therapy Position Statement. Cytotherapy, 8, 315-317.

Eglinton, T. W., Barclay, M. L., Gearry, R. B., \& Frizelle, F. A. (2012). The spectrum of perianal Crohn's disease in a population-based cohort. Diseases of the Colon \& Rectum, 55, 773-777.

Gecse, K. B., Bemelman, W., Kamm, M. A., Stoker, J., Khanna, R., Ng, S. C., et al (2014). A global consensus on the classification, diagnosis and multidisciplinary treatment of perianal fistulizing Crohn's disease. Gut, 63, 1381-92.

Georgiev-Hristov, T., Guadalajara, H., Herreros, M. D., Lightner, A. L., Dozois, E. J., García-Arranz, M., et al (2018). A Step-By-Step Surgical Protocol for the Treatment of Perianal Fistula with Adipose-Derived Mesenchymal Stem Cells. Journal of Gastrointestinal Surgery, 22 (11), $2003-2012$.

Ingle, S. B., \& Loftus, E. V. Jr (2007). The natural history of perianal Crohn's disease. Digestive and Liver Disease, 39, $963-969$.

Karp, J. M., \& Teo, G. S. L. (2009). Mesenchymal Stem Cell Homing: The Devil Is in the Details. Cell Stem Cell, 4.

Kagramanova, P., Knyazev, N., \& Konoplyannikov, A (2016). The combined of mesenchymal stem cells and infliximab reduces the recurrence rate of Crohn's disease. Journal of Crohn's and Colitis, 10 (1), 346.

Kachgal, S., \&Putnam, A. J (2011). Mesenchymal stem cells from adipose and bone marrow promote angiogenesis via distinct cytokine and protease expression mechanisms. Angiogenesis, 14 (1), 47-59.

Kim, W. S., Park, B. S., Sung, J. H., Yang, J. M., Park, S. B., Kwak, S., et al (2007). Wound Healing Effect of Adipose-Derived Stem Cells: A Critical Role of Secretory Factors on Human Dermal Fibroblasts. Journal of Dermatological Science, 48 (1), 15-24.

Kreuter, R., Wankell, M., Ahlenstiel, G., \& Hebbard, L (2019). The role of obesity in inflammatory bowel disease. Biochimica et Biophysica Acta - Molecular Basis of Disease, 1865, 63-72. 
Research, Society and Development, v. 11, n. 1, e575111252992, 2022

(CC BY 4.0) | ISSN 2525-3409 | DOI: http://dx.doi.org/10.33448/rsd-v11i1.25299

Lightner, A. L., \& Faubion, W. A (2017). Mesenchymal Stem Cell Injections for the Treatment of Perianal Crohn's Disease: What We Have Accomplished and What We Still Need to Do. Journal of Crohn's \& Colitis, 11 (10), 1267-1276.

Markarian, C. F., Frey, G. Z., Silveira, M. D., Chem, E. M., Milani, A. R., Ely, P. B. et al (2014). Isolation of adipose-derived stem cells: a comparison among different methods. Biotechnology Letters, 36 (4), 693-702.

Molendijk, I., Bonsing, B. A., Roelofs, H., Peeters, K. C., Wasser, M. N., dijkstra, G., et al (2015). Allogeneic Bone Marrow-Derived Mesenchymal Stromal Cells Promote Healing of Refractory Perianal Fistulas in Patients with Crohn's Disease. Gastroenterology, 149 (4), 918-927.

Ng, S. C., Shi, H. Y., Hamidi, N., Underwood, F. E., Tang, W., Benchimol, E. I., et al (2017). Worldwide incidence and prevalence of inflammatory bowel disease in the 21st century: a systematic review of population-based studies. The Lancet, 390 (10114), 2769-2778.

Ott, C., \& Schölmerich, J (2013). Extraintestinal manifestations and complications in IBD. Nature Review Gastroenterology Hepatology, 10, 585-595.

Panés, J., García-Olmo, D., Van Assche, G., Colombel, J. F., Reinisch, W., Baumgart, D C., et al (2018). Long-term Efficacy and Safety of Stem Cell Therapy (Cx601) for Complex Perianal Fistulas in Patients with Crohn's Disease. Gastroenterology, 154 (5), 334-1342.

Pesarini, J. R., Oliveira, R. J., Pessatto, L. R., Antoniolli-Silva, A. C. M. B., Felicidade, I., Nardi, N. B., et al (2017). Vitamin D: Correlation with biochemical and body composition changes in a southern Brazilian population and induction of cytotoxicity in mesenchymal stem cells derived from human adipose tissue. Biomedicine \& Pharmacotherapy, 91, 861-871.

Podojil, J. R., \& Miller, S. D. (2009). Molecular mechanisms of T-cell receptor and costimulatory molecule ligation/blockade in autoimmune disease therapy. Immunological Review, 229 (1), 337-355.

Rocha, R., Santana, G. O., Almeida, N., \& Lyra, A. C. (2009). Analysis of fat and muscle mass in patients with inflammatory bowel disease during remission and active phase. The British Journal Nutrition, 101 (5), 676-679.

Robey, P. (2017). "Mesenchymal stem cells": Fact or fiction, and implications in their therapeutic use. F1000 Research, 6, 1524.

Torres, J., Mehandru, S., Colombel, J. F., \& Peyrin-Biroulet, L (2017). Crohn's disease. The Lancet, 389, 1741-1755.

Van Assche, G., Vanbeckevoort, D., Bielen, D., Coremans, G., Aerden, I., Noman, M et al (2003). Magnetic resonance imaging of the effects of infliximab on perianal fistulizing Crohn's disease. The American Journal of Gastroenterology, 98, 332-339.

World Health Organization (WHO). (1995). Physical status: the use and interpretation of anthropometry. Technical Report Series, Geneva, 452 p. https://apps.who.int/iris/handle/10665/37003

World Health Organization (WHO). (1998). Obesity: preventing and managing the global epidemic. Technical Report Series, Geneva, n. 894. https://apps.who.int/iris/handle/10665/42330

Zhang, H., Zeng, Z., Mukherjee, A \& Shen, B (2018). Molecular diagnosis and classification of inflammatory bowel disease. Expert Review of Molecular Diagnostics, 18 (10), 867-886. 